\title{
Glycogen-Laden Hepatomegaly in Diabetes
}

\author{
By \\ G.D. Mrddefton and T.D. R. Hockaday \\ The Radcliffe Infirmary, Oxford \\ Received August 9, 1965
}

\begin{abstract}
Summary. A 43-year old man is described who had been treated with insulin for diabetes for 18 years. For the last 3 years he had had nightly hypoglycaemic attacks. $\mathrm{He}$ was then found to have an enlarged liver, biopsy of which showed normal architecture but a markedly increased glycogen content. After his insulin was changed so that he no longer developed hypoglycaemia, his liver returned to normal size and normal glycogen content. Previous reports of glycogen-laden hepatomegaly are reviewed, and its mechanism is discussed, with special reference to its reversibility when hypoglycaemia is avoided.
\end{abstract}

Résumé. Les auteurs rapportentl'observation d'un homme âgé de 43 ans traité par l'insuline depuis 18 ans. Pondant les 3 dernières années il souffrait d'attaques nocturnes d'hypoglycémie. On constata une augmentation du foie dont une biopsie démontra une architecture normale, mais des dépôts considérablement élevés de glycogène. Après abolition des hypoglycémies par changement d'insuline, le volu- me et le contenu de glycogène du foie redevinrent normaux. Des rapports antérieurs d'hépatomégalie par dépôt glycogénique sont passés en revue; le mécanisme de cette hépatomégalie et particulièrement sa reversibilité, si l'hypoglycémie est évitée, est discuté.

Zusammenfassung. Bericht über einen 43-jährigen Mann, der wegen seines Diabetes 18 Jahre lang mit Insulin behandelt wurde. In den letzten 3 Jahren hatte er nächtliche hypoglykämische Anfälle. Die Untersuchung ergab eine vergrößerte Leber, deren bioptische Untersuchung eine normale Struktur, aber einen deutlich erhöhten Glykogengehalt erkennen ließ. Nachdem das Insulin gewechselt wurde, sodaß Hypoglykämien nicht mehr auftraten, bildete sich die Lebervergrößerung zurück. Sie enthielt jetzt normale Mengen von Glykogen. Über frühere Angaben der ,glycogen-laden hepatomegaly" wird berichtet, ihr Entstehungsmechanismus diskutiert, wobei besonders die Reversibilität des Zustandes berück. sichtigt wird, wenn Hypoglykëmien vermieden werden.
Hepatomegaly has often been described in diabetic patients (GOODMAN, 1953) and ascribed to fatty infiltration, except in a few reports when the authors have suspected or demonstrated excessive hepatic deposition of glycogen. In only one of these (STETSON and OHLER, 1937) was disappearance of the hepatomegaly noted, but no serial determinations of glycogen content were made; the presence of jaundice in this case made the aetiology of the hepatomegaly uncertain. In the present article hepatomegaly is described in a diabetic patient who had received too much insulin for many years. His liver contained an abnormally large amount of glycogen by histological examination. When hypoglycaemic attacks were avoided by change in treatment his liver returned to a normal size and a second biopsy showed it to have a normal glycogen content.

\section{Case History (Radcliffe Infirmary No. 357904 )}

A man of 43 was transferred to the care of Dr. A.M. CoOKE from another hospital because of glycosuria, ketosis, frequent hypoglycaemic attacks, hepatomegaly and abdominal pain.

He had developed typical diabetic symptoms of weight loss, thirst and polyuria in 1943 when aged 25 years. His blood sugar was $490 \mathrm{mg} \%$ at his first visit to hospital. He was treated with a Lawrence Line diet and Soluble Insulin 10 units twice daily. On this regime he was free of symtoms for ten years although he attended the Diabetic Clinic infrequently. He had considerable glycosuria in 1953 and his dose of insulin was raised to 24 units morning, 22 units evening. Subsequently he had occasional episodes of hypoglycaemia. In 1961 he was admitted to hospital in hypoglycaemic coma. The first blood for glucose analysis was drawn after intravenous injection of glucose but the glucose concentration was only $90 \mathrm{mg} \%$. During this admission the patient was shown to have a low renal threshold for glucose. However, when he was discharged from hospital his Soluble Insulin had been increased to 55 units morning, 44 units evening.

From 1961 to 1964 he had nightly attacks of hypoglycaemia, with sweating, tremor, and mental confusion, but by day there was marked glycosuria, and often ketosis. The glycosuria, nearly always present because of his low renal threshold, was exacerbated by carbohydrate used to treat or prevent hypoglycaemic attacks. In November 1963 he was readmitted to hospital in hypoglycaemia and his Soluble Insulin was reduced to 20 units twice daily. The following month, however, he was readmitted, this time in diabetic coma, and hepatomegaly was recorded for the first time. The liver was enlarged to the level of the umbilicus and was tender on palpation. The patient complained of recurrent attacks of severe upper abdominal pain, aching in character but unrelated to meals. Because a barium meal and a cholecystogram were both normal, a laparotomy was done to determine the nature of the enlarged liver. Hepatomegaly to 4 fingers breadth below the costal margin was confirmed, and the liver was seen to be firm and pale. The spleen was slightly enlarged. Histological examination of liver tissue removed at operation showed heavy infiltration with glycogen, plentiful fat, but no inflammation or disorganization (Fig. 1). After the laparotomy, while taking Soluble Insulin 14 or 16 units three times daily, he continued to have hypoglycaemic attacks, ketonuria, and gross glycosuria.

On 27th February, 1964, when the patient was transferred to the Radcliffe Infirmary, he was sweating freely on examination and had some tremor of the outstretched 


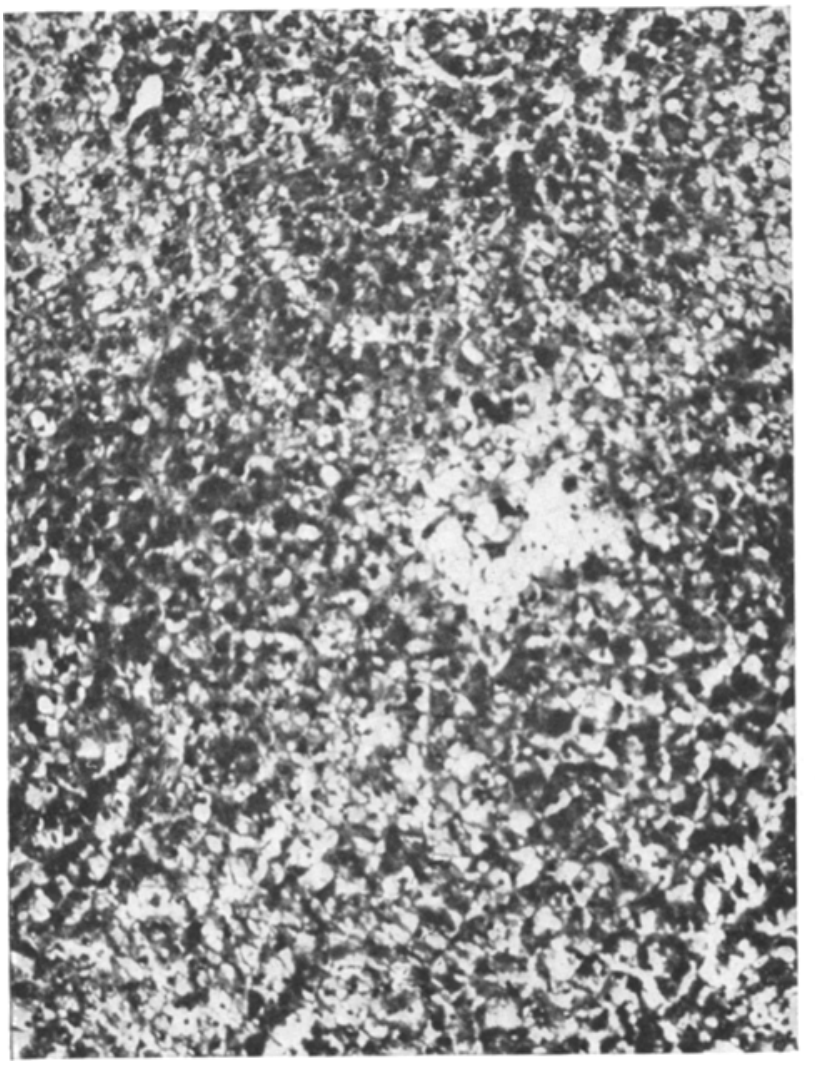

Fig. 1. Initial Liver Biopsy stained for Glycogen, $\times 100$.

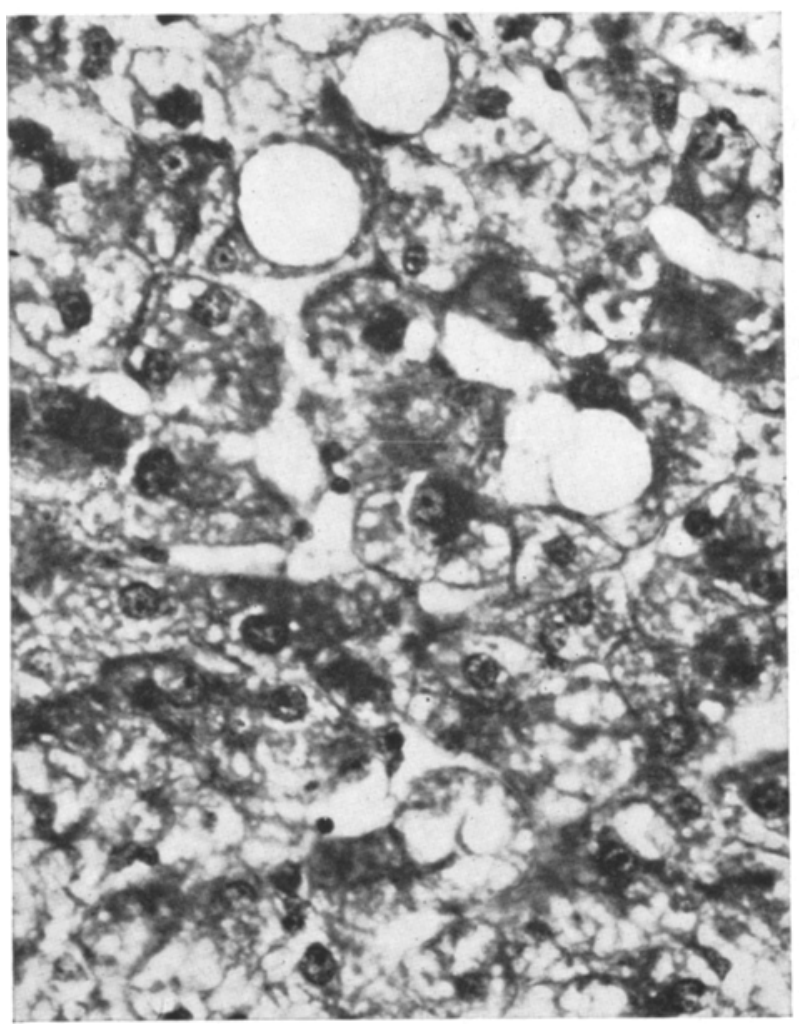

Fig. 1 a. Initial Liver Biopsy stained for Glycogen, $\times 400$.

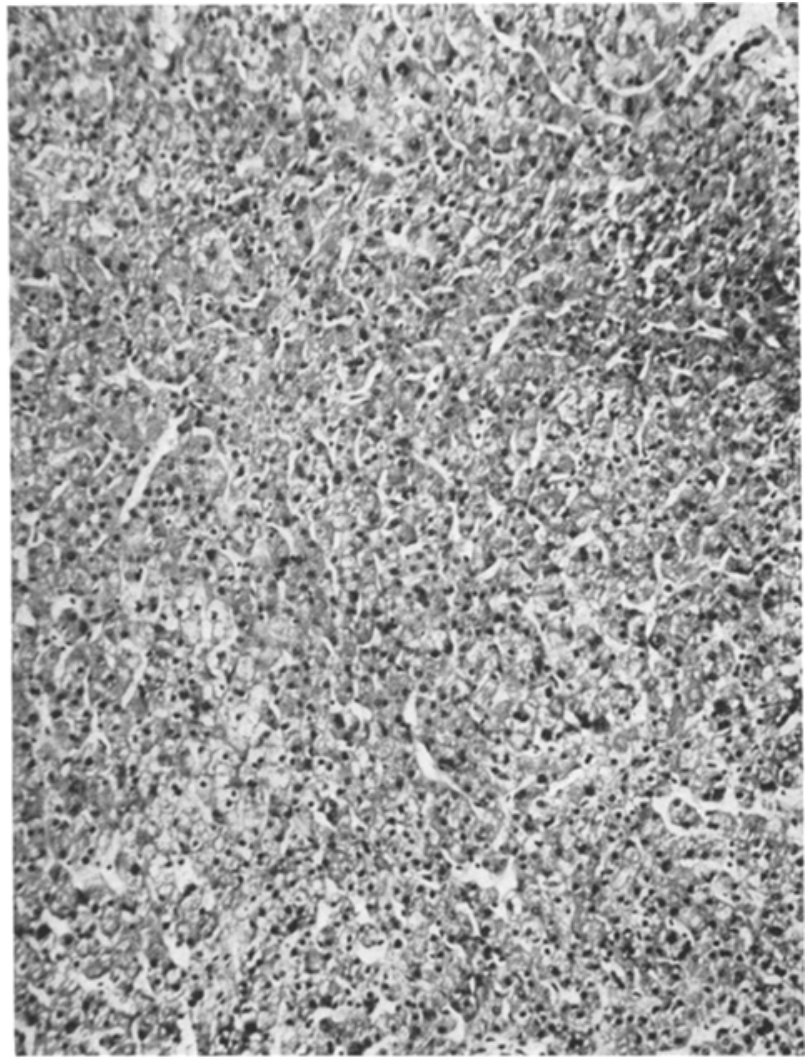

Eig. 2. Second Liver Biopsy stained for Glycogen, $\times 100$.

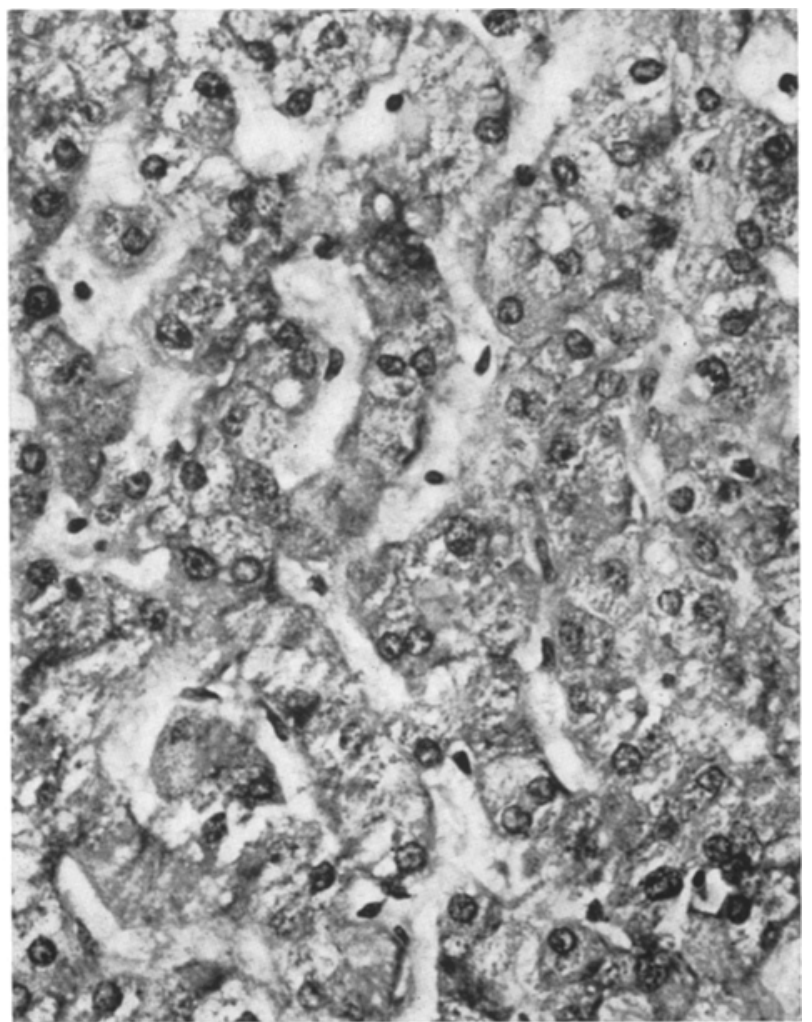

Fig. 2a. Second Liver Biopsy stained for Glycogen, $\times 400$. 
fingers. His breath smelt heavily of acetone. The abdomen was distended, there was epigastric tenderness with guarding and the liver was palpable $10 \mathrm{cms}$. below the costal margin. There was no evidence of diabetic neuropathy, nephropathy, retinopathy or generalised vascular disease.

Investigations showed a haemoglobin of $14.2 \mathrm{G} / 100 \mathrm{ml}$ and white blood cell count of 4200 per cu.mm. (with normal blood film). The urine contained no protein, no excess of urobilinogen and no casts. Blood urea was $28 \mathrm{mg} / 100 \mathrm{ml}$ and plasma electrolytes were normal except for a bicarbonate of $18 \mathrm{mEq} / \mathrm{L}$. Serum cholesterol was $215 \mathrm{mg} / 100 \mathrm{ml}$, while serum proteins and bilirubin were normal. The alkaline phosphatase, however, was raised to $21 \mathrm{King}$ Armstrong units while the serum glutamic-pyruvic transaminase was initially 210 but fell with treatment to 64 and finally 9 units. The blood sugar varied initially (from $210 \mathrm{mg} / 100 \mathrm{ml}$ on admission to $305 \mathrm{mg} / 100 \mathrm{ml}$ ) but it finally improved and then ranged from 120 to $250 \mathrm{mg} /$ $100 \mathrm{ml}$ on Soluble Insulin 24 and Protamine Zinc Insulin 24 units daily. The blood total ketone body concentration (measured by Dr. M. BerRY by the enzymic method of Willtamson, Merlanby and KreBs, 1962) was $1.61 \mu \mathrm{M}$ $\mathrm{ml}$ (ratio $\beta$-hydroxy-butyrate: acetoacetate $=0.9$ ) when taken fasting 5 days after admission, and $0.76 \mu \mathrm{M} / \mathrm{ml}$ (ratio 2.2) when taken $21 /$ hours after lunch 9 days after admission. The first of these values is well above the normal range of $0.05-0.88 \mu \mathrm{M} / \mathrm{ml}$. Glycosuria persisted, though much decreased, but the initial ketonuria soon disappeared.

The patient continued to complain of abdominal pain, and intermittent diarrhoea. Barium meal with examination of the small intestine was normal (there was no pancreatic calcification) as was a barium enema. Jejunal and rectal biopsies obtained normal tissue, while sigmoidoscopy was also normal. Cholecystogram was normal. The stools contained $9 \mathrm{G}$ fat per $24 \mathrm{hrs}$. In a $5 \mathrm{G}$ Xylose absorption test $37 \%$ of the administered dose was excreted in the urine in the first $5 \mathrm{hrs}$. Faecal culture was normal. X-ray of the spine showed increased density of the tenth thoracic vertebra, probably due to Pagets disease.

Investigations to test whether the blood glucose concentration could be increased by glycogenolytic agents are listed in the Table. There was a rise in the blood glucose

Table. Blood glucose after injections of glucagon or adrenaline

A. $0.1 \mathrm{mg}$ glucagon $i . v$. before morning insulin, with overnight fast

Time (mins) from injection $\begin{array}{llllll}-15 & 0 & 15 & 25 & 55\end{array}$ $\begin{array}{llllll}\text { Blood glucose }(\mathrm{mg} / 100 \mathrm{ml}) & 319 & 311 & 322 & 314 & 322\end{array}$

B. $0.2 m g$ glucagon $i . v$. at 3 p.m., $21 / 2$ hrs. after lunch

Time (mins) from injection $-15 \quad 0 \quad 15 \quad 40$ $\begin{array}{lrrrr}\text { Blood glucose }(\mathrm{mg} / 100 \mathrm{ml}) & 99 & 105 & 116 & 140\end{array}$

\section{Adrenaline, $0.5 \mathrm{ml} 1: 1000 \mathrm{sol}$. (B.P.) SC}

Time (mins) from injection $\begin{array}{llllll}-10 & 0 & 20 & 40 & 60 & 80\end{array}$ $\begin{array}{lllllll}\text { Blood glucose }(\mathrm{mg} / 100 \mathrm{ml}) & 75 & 85 & 90 & 95 & 115 & 125\end{array}$

concentration after $0.2 \mathrm{mg}$. glucagon and after adrenaline. The failure of the first injection of glucagon might have been because of the smaller dose used, or because the injection was made when the blood glucose was increased. Hudoes, Sherrock and WaLshe (1949) found that the level of the blood glucose concentration did not affect the increase of blood glucose after injection of adrenaline in normal subjects, but this conclusion need not apply to diabetics.

In summary, these tests indicated that the liver glycogen could be converted into blood glucose, and excluded the absence of any enzyme necessary for the breakdown of the glycogen such as is found in some of the glycogenoses (CORI, 1957).

The patient's course during this admission was satisfactory. Diabetic control was achieved with a combination of Soluble Insulin 20 units and Protamine Zinc Insulin 24 units. No further hypoglycaemic attacks occurred and during the following four weeks the liver decreased until at discharge on 10/4/64 it was no longer palpable. Two weeks later the patient was admitted in diabetic precoma (blood sugar $530 \mathrm{mg} \%$, gross ketonuria, and plasma bicarbonate $12 \mathrm{mEq} / \mathrm{L}$ ). After a further long period in hospital, during which he had several episodes of abdominal pain and much constipation, his diabetes was restabilised on Soluble Insulin 24 units and Protamine Zine Insulin 20 units. He was discharged and his diabetes remained well controlled but he continued to complain of abdominal pain. He was therefore readmitted on $15 / 7 / 64$ and seen in consultation with Mr. C. U. WeBsTer. Because of the triad of weight loss, abdominal pain and steatorrhoea, intestinal ischaemia was considered a possible cause of his symptoms. Another barium meal, a second faecal fat and a mesenteric angiogram were all normal. Nevertheless, as the patient continued to complain of severe abdominal pain, a second laparotomy was performed.

At this operation no abnormality was discovered. A further biopsy, taken from a now macroscopically normal liver, showed a normal structure and a normal amount of glycogen on microscopical examination (Fig. 2). Since this operation the patient has remained well.

\section{Discussion}

Hepatic enlargement is not uneommon in diabetics. GoodMaN (1953) observed it in $45 \%$ of those poorly controlled as against $9 \%$ in those well controlled and $15 \%$ of those with ketoacidosis. He considered fatty infiltration the cause of the hepatomegaly, as did Hanssex (1936) who recorded regression of hepatomegaly after transfer to protamine zine insulin of 13 young diabetics who had been difficult to control on large doses of soluble insulin.

WHITE (1932) also noted hepatomegaly in young diabetics but she argued that the enlargement was because of abnormal storage of glycogen. Support for her view came from two case reports (BRIAN, Schechter and Persons, 1937; Sterson and OHLER, 1937) where diabetic hepatomegaly was associated with increased glycogen content of the liver on histological examination. In both instances the patients had been receiving increasing doses of soluble insulin and experiencing hypoglycaemic symptoms. One patient was jaundiced (STETSON and OHLER, 1937), and the hepatomegaly may have had a cause apart from his diabetes. A review of the glycogen content of the liver cells in various hepatic diseases found it raised only in some conditions with diffuse liver damage obvious even on needle biopsy (BianciII and La Torre, 1962).

It was not until 1955 that the claim was made for a syndrome of recurrent hypoglycaemia during insu- 
lin treatment, with hepatomegaly and excessive glycogen concentration, in young diabetics, difficult to control and receiving large doses of insulin (Evans, LitTher and Pembertor, 1955). Ketosis was frequent in the four patients described. Glucagon intravenously (dose not specified) had little or no effect on the blood glucose, but the blood glucose was always over $400 \mathrm{mg} / 100 \mathrm{ml}$ when the glucagon was injected. The hypoglycaemia was partially controlled by adrenaline or thyroxine which was thought to indicate that the liver glycogen could be broken down to glucose.

Meanwhile a study of livers from the dead (VALLANCE-OWEN, 1952) had shown the hepatic glycogen content of diabetics dying in coma to be often as great or greater than that of non-diabetics. HrLdws, SHERLOCK and WALSHE (1949) had shown in the living that diabetics had no lowering of liver glycogen. They also recorded, in 2 patients with "acute, insulin-requiring" diabetes, a paradoxical response to the intravenous infusion of adrenaline in an increase of liver glycogen concentration; and they noted, again paradoxically, that 10 out of their 13 diabetic subjects had a decrease in blood glucose 15 minutes after the adrenaline infusion began.

The patient reported here seems similar to the patients of Evans et al. (1955), and perhaps those of Hanssen (1936), although he is older than any diabetic previously reported to have a large liver because of excessive deposition of glycogen. The low renal threshold for glucose made management of his diabetes difficult and he developed severe hyperglycaemia four times. However, for at least 3 years he had nightly hypoglycaemic attacks. This, implying excessive action of insulin, together with the extra carbohydrate given to him to treat or prevent hypoglycaemia, can relatively easily explain the high concentration of liver glycogen found at the first biopsy. The excess insulin produced endogenously by a pancreatic islet-cell tumour has similarly been thought to cause an abnormally high concentration of liver glycogen (WILDER, Aluen, Power and Robertson, 1927).

There are other reasons, associated with the frequent hypoglycaemia and ketonaemia, why a large amount of hepatic glycogen might occur in the patient reported here. Although insulin promotes triglyceride formation by adipose tissue (STETTEN and BoxeR, 1944; Randle, Garland, Hales and Newsholme, 1963), when the dose of insulin is large enough to produce hypoglycaemia reactions occur that result in mobilisation of fat. These include secretion of adrenaline (Houssay, Lewis and Molineuti, 1924), adrenocorticotrophic hormone (ACTH) (LANDON, WYNN and JAMES, 1963), and growth hormone (RoTH, GLICK, YALOW and Berson, 1963). All these agents, directly or indirectly (e.g. ACTH perhaps by causing secretion of cortisol), have been shown to elevate the concentration of plasma non-esterified fatty acids in vivo and to be capable of increasing lipolysis in adipose tissue in vitro. An increased uptake of fatty acid by the liver may therefore be expected to occur, with two probable consequences.

First, the catabolism of carbohydrate in the liver would decrease, either solely because of competition for hydrogen acceptors with another fuel, or also because fatty acids in excess might directly inhibit glucose oxidation, as has been suggested for muscle (RANDLE et al., 1963). Secondly, increased production of ketone bodies would be expected. It has been widely accepted that ketosis occurs when there is an excessive production of acetyl coenzyme A (KREBS, 1960). The normal regulation of the catabolism of glycogen or glucose seems to avoid such an excess which is, however, associated with increased mobilisation of fat from adipose tissue, e.g. as in starvation, prolonged exercise, excessive ingestion of fat, and lack of insulin (WreLAND and WEISS, 1963).

The insulin-requiring diabetic is deficient in one mechanism, perhaps normally important in limiting such ketogenesis. Ketonaemia excites insulin secretion in the normal dog (Madison, Mebant, Unger and LochNer, 1964) and this, in the presence of adequate carbohydrate, would increase hepatic uptake of glucose and favour carbohydrate utilisation. In a severe diabetic the same effect could be achieved only by ingesting carbohydrate or injecting insulin.

The patient described here seemed one in whom soluble insulin was particularly likely to produce hypoglycaemia, so setting in train mechanisms that result in mobilisation of fat to the liver once more. Although it is easy to see why, in our patient, there might be excessive formation of liver glycogen, and excessive conservation of it once formed, it is not clear why breakdown of liver glycogen as a reaction to hypoglycaemia did not prevent excess glycogen accumulation. It may be that, over the years, such breakdown weighed less in the balance than factors leading to glycogen accumulation. However one must also note the increase of liver glycogen after injection of adrenaline in diabetics (HILdes et al., 1949). Also to be considered are the recent queries whether adrenaline is directly involved in the breakdown of liver glycogen (SokaL and Sarcione, 1964), and the unknown importance of glucagon (KIBLER, TAYLOR and MYERS, 1964) and of serotonin (Levine, Pesch, KLatskin and Giarman, 1964).

The capacity for enzyme production in the liver would not be expected to be affected by the excess utilisation of lipid which we have suggested to follow repeated hypoglycaemia. Once hypoglycaemia was avoided by reducing the dose of soluble insulin it is not surprising that ketonaemia ceased, the store of liver glycogen gradually disappeared, and the liver returned to its normal size.

\section{Acknowledgments}

The authors wish to thank Dr. A.M. Cooke for permission to publish details of his patient, and for his help in preparation of this article. 


\section{References}

Bianchi, P., and F. LA Torre: The glycogen content of the liver cells in various liver diseases. Panminerva Med., 4, 444-449 (1962).

Brian, E. W., A.J. Schechter, and E. L. Persons: Unusual glycogen storage in a case of diabetes mellitus. Arch. int. Med., 59, 685-690 (1937).

CorI, G.T.: Biochemical aspects of glycogen deposition diseases. Mod. Probl. Pediat., 3, 344 (1957).

Evans, R.W., T.R. Littler, and H. S. Pemberton : Glycogen storage in the liver in diabetes mellitus. J. Clin. Path., 8, 110-113 (1955).

Goodman, J. I.: Hepatomegaly and diabetes mellitus. Ann. Int. Med., 39, 1077-1087 (1953).

Hanssen, P.: Enlargement of the liver in diabetes mellitus. J. Amer. med. Assoc., 106, 914-916 (1936).

Hildes, J. A., S. Sherlock, and V. WAlshe: Liver and muscle glycogen in normal subjects, in diabetes mellitus, and in acute hepatitis. Clin. Sci. $7,287-297(1949)$

Houssay, B.A., J. T. Lewrs, and E. A. Molrnelur : Rôle de la sécrétion d'adrénaline pendant l'hypoglycémie produite par l'insuline. C. R. Soc. Biol. (Paris) 91, $1011-$ 1013 (1924).

KIBLER, R.F., W.J. TAYLOR, and J. D. MYERS : T'ne effect of glucagon on net splanchnic balances of glucose, amino-acid nitrogen, urea, ketones, and oxygen in man. J. clin. Invest., 43, 904-915 (1964).

KreBs, H.A.: Biochemical aspects of ketosis. Proc. Roy. Soc. Med., 53, 71-80 (1960).

LANDON, J., V. WYNN, and V.H.T. JAMES: The adrenocortical response to insulin-induced hypoglycaemia. $J$. Endocr., 27, 183-192 (1963).

Levine, R.A., L.A. Pesch, G. Kiatskin, and N. J. GIARMAN : Effect of serotonin on glycogen metabolism in the isolated rat liver. J. Clin. Invest., 43, 797-809 (1964).

Madison, L.L., D. Mebane, R.H. Unger, and A. Loch-
NER: The hypoglycemic effect of ketones. II Evidence for a stimulatory feedback of ketones on the pancreatic beta cells. J. Clin. Invest., 43, 408-415 (1964).

Randle, P.J., P.B. Gartand, C.N. Hales, and E.A. Newsholme: The glucose-fatty acid cycle. Its role in insulin sensitivity and the metabolic disturbances of diabetes mellitus. Lancet, 1, 785 (1963).

Roth, J., S.M. Glick, R.S. Yalow, and S.A. Berson: Secretion of human growth hormone: Physiologic and experimental modification. Metabolism, 12, 577-579 (1963).

SokaL, J.E., and E.J. SARctone: Failure of physiological concentrations of epinephrine to affect glycogen levels in the isolated rat liver. Nature, 204, 881-883 (1954).

Stetson, R.P., and W.R. OHLer: Hepatomegaly and jaundice in a juvenile diabetic. New Engl. J. Med., 217, $627-629$ (1937).

Stetten, W. DE, JR., and G.E. Boxer: Studies in carbohydrate metabolism. III Metabolic defects in alloxan diabetes. J. biol, Chem., 156, 271-278 (1944).

VALIANCE-OWEN, J.: Liver glycogen in diabetes mellitus. J. Clin. Path., 5, 42-53 (1952).

WHrTe, P.: "Diabetes in Childhood and Adolescence" Philadelphia, Lea and Febiger, p. 66 (1932).

WImLaNd, O., and L. WEISS: Increase in liver acetylcoenzyme. A during ketosis. Biochem. Biophys. Res. Comm., 10, 333-339 (1963).

Wmoter, R.M., F.N. Allen, M.H. Power, and H.E. RoBertson: Carcinoma of the islands of Langerhans. J.A.M.A., 89, 348-355 (1927).

Williamson, D.H., J. Mellanby, and H.A. Krebs: Enzymic determination of D-(-)- $\beta$-hydroxy-butyric acid and acetoacetic acid in blood. Biochem. J., 82, 90-96 (1962).

Dr. G. D. Mrodleton

The Radeliffe Infirmary

Oxford/England 